\title{
THE LIVERPOOL DOCK STRIKE OF I890
}

The strike of stevedores and dock labourers in the Port of London in 1889 has come to symbolise that ferment and upsurge of labour activity, in favour of combined action, which found expression in the "new unionism". Indeed the great spread of union organisation in the London area at this period has usually been regarded as the main phase of new unionism. ${ }^{1}$ It is true that labour historians have long been aware that widespread agitation and union recruitment were also afoot among both provincial dockers and other groups who had been either unorganised, or whose previous attempts at unionism had proved sporadic and abortive. ${ }^{2}$ The Liverpool dockers, in particular, became engaged in 1890 in a protracted struggle involving almost as great a number of strikers as on the London docks in the previous year. ${ }^{3}$ This Liverpool strike had all the makings of a "labour war", and it resulted in a profound impact upon industrial relations on the Mersey waterfront. However, the events and consequences of this dispute together with the activities of the National Union of Dock Labourers which organised it have so far received less detailed attention than either the dock strike in the metropolis or the London dockers union..$^{5}$

It is the purpose of this paper to attempt to restore the balance somewhat and, in particular, to examine the actions and attitudes of rank-and-file unionists, as well as those of their leaders. At the same time the events of the 1890 strike will be interpreted from the stand-

1 Henry Pelling, A History of British Trade Unions (1963), p. 97.

2 See H. A. Clegg, Alan Fox and A. F. Thompson, A History of British Trade Unions Since 1889, Vol. I : 1889-1910 (1964), pp. 56-66.

3 Report on the Strikes and Lockouts of 1889 [Cd 6176 and 6476] (1890-91).

4 Liverpool Citizen, 12 March 1890.

5 For London see H. Llewellyn Smith and Vaughan Nash, The Story of the Dockers Strike (1890); J. Lovell, Stevedores and Dockers (1969); and Royal Commission on Labour, Group B, Vol. I [Cd 6708] (1892). 
point of contemporary industrial relations and dispute analysis, which views industrial strife as a surface symptom of more fundamental characteristics of rule making and administration within a given industrial relations context. ${ }^{1}$ Thus, the focus will be on the rules of job regulation and the interplay of technical, market and power forces which shape, and change, an industrial relations "system".

The development of a system of job regulation on the waterfront is a function of the specialised characteristics of this particular industry and those conditions peculiar to a particular port. The modern port of Liverpool with a system of docks extending for seven miles in a north to south direction dates from 1857 when the Mersey Docks and Harbour Board (MDHB) was formed. The intention was to vest authority for running the port as a commercial enterprise in a single body which thereafter would treat the Mersey not "like a fishpond of King John's but [as] a national highway of commerce". ${ }^{2}$ The Board soon embarked on a policy of improving and extending the accommodation of the port to cope with rapidly growing trade. In addition, accommodation for deeper and longer ships was required because steam was coming to displace sail as the source of power for ocean transportation. By 1883 a vast extension of the dock system had been completed with five new docks added in the deep water at the north end for the largest class of steamers, particularly in the Atlantic trade, and a further two at the south end to cater for smaller steamers and the remaining sailing ships. However, the needs of steamships were not only for improved dock and quay accommodation but, as a result of the high cost of keeping them in port, for greater speed of loading and unloading in turn-round. The more leisurely methods of cargo handling used on sailing ships ${ }^{3}$ were no longer appropriate. Consequently mechanical handling in the form of portable steam engines and hoists for loading and discharging ships were introduced in the mid 1870 s and ten years later elevators for discharging bulk cargoes such as grain, which lent themselves more readily to mechanical methods. These devices would displace manual labour and in 1876 an unsuccessful petition to the MDHB from nineteen thousand dock labourers had requested prohibition of steam engines on the quays - each engine being said to displace from eight to sixteen men. ${ }^{4}$

Cargo handling on the quays was the responsibility of the master

1 J. T. Dunlop, Industrial Relations Systems (1958), p. 380.

2 Quoted in S. Mountfield, Western Gateway: A History of the Mersey Docks and Harbour Board (1965), p. 10.

3 Ibid., p. 34.

4 Liverpool Weekly Mercury, 12 February 1876. 
porter and his employees (quay porters) and in the case of sailing ships control of the master porterage system was vested in traffic managers of the Docks and Harbour Board. But for steamships the emphasis was upon a speedy clearance of the quays and therefore steamship owners with "appropriated" berths (i.e. dock accommodation set aside for their exclusive use) had direct control of goods on the quay, whereas those without appropriations were linked with sailing ship owners for purposes of master porterage. ${ }^{1}$ A dual system also operated in Liverpool for the loading and discharge of cargoes on ship. The "master lumper" was responsible for discharging the cargo whereas the work of loading the vessel would be either contracted to master stevedores who employed that category of dockers known as "shipmen" (or stevedores2) or, in some cases, the shipowner would dispense with the contractor and employ his own men direct. It was often claimed that dockers secured better conditions of employment from the shipowner than from the contractor or middleman. ${ }^{3}$ In practice independent firms of master porters and stevedores were used more by the smaller shipping firms in the south docks, whereas in the appropriated berths for the transatlantic trade at the north end they were nominees for the larger shipping companies and therefore more specific to them.

In fact the system of distributing dock labour was in many respects haphazard and near chaotic. Each employer held his stand at $7 \mathrm{am}$. with the result that there was no time for men not required at one stand to go on to another and no knowledge of whether they would be required there. Similarly, because of the distance between one end of the docks and the other the north and south docks formed effectively two distinct labour markets with little mobility between them. ${ }^{4}$ In Liverpool the shipmen and quay porters also formed two separate classes of workers with little interchange among them. Shipmen were paid at a higher rate than quay porters, in the form of a differential of $6 \mathrm{~d}$. a day, but work on ship was more dangerous and, for men in the hold, required a fast pace in order to keep up with the winches. For both categories the work was casual, employment being for a minimum period of half a day - unlike London where men were taken on, dis-

${ }^{1}$ See Abstract of Evidence, taken before a special committee of the MDHB in reference to Dock Accommodation of the Port 1872, p. 50.

2 Stevedores proper, however, were an exclusive majority, who received high pay, at the rate of $7 /$ - for day work and $12 /$ - for night work in 1890 , for their responsible duty of correctly stowing the cargo. See E. F. Rathbone, An Enquiry into the Conditions of Dock Labour at the Liverpool Docks (1904).

${ }^{3}$ Royal Commission on Labour, Group B, Vol. II [Cd 6795] (1892), q. 13579.

E. F. Rathbone, op. cit., p. 9. 
charged and paid on an hourly basis. However, the purely casual nature of the work and the practically open market for labour was somewhat modified by the practice of employer preference for known and experienced men rather than for strangers and casuals. ${ }^{1}$ It was in his interest to keep men attached to his stand so that they would be on hand at busy times, such as for the arrival of the cotton crop in October or the passenger emigration trade in summer, when pressures arose with the vicissitudes of port work. At one period Cunard had employed regular men on a weekly basis, but paid them at a lower rate than firms employing casual daily labour. ${ }^{2}$ This practice had ended in 1872 when, in conditions of revitalised trade, wages were increased and the men preferred the higher daily rate.

The supply of dock labour in the port was augmented still further as a result of the nominally high wages which were offered. The daily rates of $5 /-$ on ship and $4 / 6 \mathrm{~d}$. on quay paid almost continuously from 1872 onwards, and high in comparison with most other ports, were said to be a "beacon light" attracting men from other parts of the country in the hope of regular employment at the daily rate i.e. weekly earnings of $30 /-.^{3}$ In fact many dockers could obtain only two or three days work a week, giving average earnings which did not exceed $15 /-{ }^{4}$ But the point was not merely that men would migrate to the Liverpool docks in search of employment and high weekly earnings, thereby creating an over-supply of labour, because had there been no work for them they would soon have returned. Rather the fact was that such men were given the odd day's work and a "turn all round" in order to increase the employers' labour reserves. Such men were therefore encouraged to remain. ${ }^{5}$ The permanent surplus of labour was further increased by building labourers who drifted to the docks in the winter months and men from other trades who had fallen out of work. Thus, it has been estimated that between 1861 and 1889 the number of dock labourers at least doubled, from 12,000 to $24,000^{6}$ whereas tonnage of shipping annually entering the port over the same period increased somewhat less proportionately, from five to nine million tons. ${ }^{7}$ Even when trade was brisk shipowners claimed that

1 Ibid., p. 8.

2 Liverpool Mercury, 20 June 1872.

3 Liverpool Review, 5 April 1890. For comparative rates of pay in various ports see Liverpool Mercury, 11 March 1890.

4 Royal Commission on Labour, Group B, Vol. II, q. 13577.

5 Report of the Commission of Inquiry into the Subject of the Unemployed in the City of Liverpool, 1894 , p. 84.

- Daily Courier, 3 March 1890.

7 MDHB, Statistics Showing Number and Tonnage of Vessels Which Paid Port Rates. 
there were never more than 13,000 dockers regularly employed. ${ }^{1}$ The labour market had come to be overstocked especially at the north end where, after 1883, the new docks were in full swing loading and discharging large steamers. Many of the Liverpool dockers had left their accommodation in the central parts of the city to look for work there, ${ }^{2}$ despite more adverse working conditions such as a night's work consisting of ten hours whereas in the south docks only nine hours were worked. ${ }^{3}$

Changes in the product market environment also had repercussions on the employment and conditions of dock labour. The emergence of the steamship not only speeded up the tempo of dock work but also resulted in a rapid increase in the number of shipping companies in Liverpool in the 1870 s, many of them being only single-ship companies. ${ }^{4}$ Competitive pressures from a large number of home-based and foreign ships together with an obdurate entrepreneurial conservatism on the part of some local shipowners, manifesting itself in "unwillingness to accept innovation either in the design of ships or in the well tried methods of commercial procedure"5 - all these resulted in declining average net profits of Liverpool shipping lines between 1871 and $1890 .^{6}$ There were repercussions on the contractor system, master porterage rates had been trimmed ${ }^{7}$ and some master stevedores were putting pressure on labour standards by reducing the numbers of men required for a specific task, as well as making hours of work more irregular by working men through the lunch hour and for an extra half hour at the end of the day for no extra pay. ${ }^{8}$ Thus competition had proved a perpetual threat to the earning capacity of shipping lines by reducing freight rates. The obvious answer was for firms to attempt to regulate it by coming to terms with their rivals. In some cases this was done, for example from 1879 in the Far Eastern Trade, by agreement to charge the same freight rates on cargo liner shipments under the "conference" system. ${ }^{9}$ Competition in freight rates was now replaced

1 Liverpool Daily Post, 25 March 1890.

2 Report of the Commission of Inquiry, op. cit., p. 101.

3 Liverpool Courier, 14 March 1890.

- F. E. Hyde, Liverpool and the Mersey: An Economic History of a Port $1700-1970$ (1971), p. 56.

F. E. Hyde, Blue Funnel: A History of Alfred Holt and Company of Liverpool (1956), p. 55.

B F. E. Hyde, Liverpool and the Mersey, p. 102.

7 Liverpool Courier, 20 January 1890.

8 Royal Commission on Labour, Group B, Vol. II, q. 13579, and Halfpenny Weekly, 14 December 1889. The arrangement was that dockers were paid overtime only if they worked for a full extra hour.

- See Report of the Royal Commission on Shipping Rings, Vol. I [Cd 4668] (1909), p. 12 . 
by competition in service so that, in effect, the company with the most efficient and speedy service would still receive the largest reward.

However, no such regulation existed in the labour market. With an abundant supply of labour wages, and the bargaining power of dockers, depended primarily upon changes in the product market. Wages might increase with improved trade but "more likely than not, as soon as the flush was over the advance would be withdrawn". ${ }^{1}$ This had happened in 1870 when an increase of $6 \mathrm{~d}$. a day was secured without any general strike, ${ }^{2}$ and again two years later. ${ }^{3}$ But wages were reduced in 1879 despite strong resistance and a lengthy strike, ${ }^{4}$ only to be restored the following year. Alternately, employers might retain the wage rate but arbitrarily increase hours of work, as in 1872 when at some docks the working day was lengthened by up to one and a half hours.

Attempts at union organisation to control market relations had been made in Liverpool during the 1860's. In 1866 the South End Dock Labourers Association was set up with registered rules and a sick and burial fund for its members and in 1872 the North End Steamship Dock Labourers Friendly Burial Society was founded. ${ }^{5}$ This latter union however soon collapsed and was replaced after the failure of the 1879 strike, at which time no formal organisation existed at the north end, by the Stevedores, Quay Porters and Dock Labourers Union. This union had some dealings over wages and hours with the Steamship Owners Association but it was not able to survive the severe depression of 1886. It is quite apparent, therefore, that to sustain union organisation on a long term basis the making of representations at periodic intervals on wages and hours, or merely performing benefit society functions, are likely to prove insufficient. Instead unions need to provide a constant service for their members in the sphere of employment relationships by their participation in job regulation. ${ }^{6}$

This was clearly shown by the development of the North End Coalheavers Society, another union founded after the 1879 strike for a specific, and exclusive, occupational group of dockworkers who loaded coal onto the Atlantic liners. The work of these employees was extremely exacting and demanded a measure of skill and experience such that they were not easily replaceable. A $£ 5$ entrance fee was imposed and the number of new members strictly controlled. By 1890 this

1 Liverpool Courier, 4 September 1889.

2 Ibid., 8 November 1870.

3 Ibid., 15 June 1872.

4 Liverpool Review, 8 February 1879.

5 Liverpool Mercury, 18 October 1872.

- See Allan Flanders, Management and Unions (1970), p. 42. 
union was said to be the most powerful in Liverpool and was strong enough to impose its own rules and regulations concerning labour upon the employers. ${ }^{1}$ Similarly the North End Labourers Union during its brief existence had made a tentative approach in this direction. Its rules stated that members would not work with non unionists and that foremen who selected men at the stands must belong to the organisation. An attempt at enforcement however, in 1872, met with such determined opposition that these rules were withdrawn as a "mistake". Nevertheless the Association at the South End managed to survive on a limited scale beyond $1900,{ }^{2}$ by securing acceptance of its rules from particular, smaller shipping firms. Even during the 1880s it had imposed fines on those members who worked with dockers not belonging to their society. ${ }^{3}$ It seems probable that smaller employers at the south end were prepared to accept union terms not because they had more personal relations with their men than in larger shipping companies, ${ }^{4}$ but rather because uniform rates and hours would help stabilise competitive conditions, i.e. whatever was imposed on them would similarly affect their competitors.

We have shown that by the mid 1880s apart from the Society of Coalheavers and the Dock Labourers Union at the south end, confined to specific groups on either an occupational or geographical basis, there were no waterfront unions at all to represent the bulk of dock workers. Yet the need for some form of labour market regulation was increasing as a result of a growing overabundance of labour, distinct labour markets at the north and south docks with disparate, and often arbitrary, conditions and hours of work and a tendency on the part of some port employers to meet competitive pressures by requiring a greater intensity of work. Similarly there were anomalies in daily wage rates for ordinary dock work in the enclosed docks where shipmen employed directly by the MDHB received only $4 / 6 \mathrm{~d}$ and quaymen $4 / 3 \mathrm{~d}^{5}$ and also no code of additional payments was laid down in Liverpool for discharging more specialised cargoes such as grain or cotton. However, with an estimated 15,000 dockers unemployed in mid $1888,{ }^{6}$ latent discontent could only be translated into effective

1 Liverpool Daily Post, 29 August 1890. The employers had attempted to break it up many times and until 1890 Cunard kept a body of scab labourers who were capable of doing the work of coaling their vessels.

${ }^{2}$ E. F. Rathbone, op. cit., p. 12. In 1890 it had about one thousand members.

${ }^{3}$ Liverpool Weekly Courier, 12 March 1887.

4 As suggested by J. Lovell, op. cit., p. 85.

5 This disadvantage was offset to some extent by greater regularity of employment.

${ }^{6}$ Liverpool Daily Post, 26 July 1888. 
action for improvement by an upturn in trade and a strengthened bargaining position. Standardisation of conditions along the docks would also necessitate organisation of dock workers on a much more comprehensive basis than hitherto.

A large meeting of dock labourers took place in Bootle at the northern docks in May 1889 under the auspices of the National Union of Dock Labourers - founded earlier that year in Glasgow - for the purpose of forming a branch in the Liverpool district. At this meeting the Glasgow organisers did not attempt to promote the union as an insurance society which would provide friendly society benefits, ${ }^{1}$ a function which was seen as central to older trade unions. In any case locally based unions would have been quite capable of performing that service. Instead, the emphasis was placed upon the national implications of their union in terms of its ability during a strike to boycott at other ports vessels belonging to a firm in dispute, and in preventing replacement dock labourers being recruited from other seaports. It was agreed to set up a Liverpool branch and, in the following month, a second branch was established at Birkenhead. The entrance fee for Birkenhead dockers was originally a shilling but the demand for membership was sufficient to encompass as many dockers as could be employed in the busiest times. Therefore, the fee was raised to $£ 1$ in order to prevent "over-stocking the market". ${ }^{2}$

Early in 1890 the union organisation in Birkenhead was completed. It had compelled master stevedores' foremen to become members, obtained improvement in hours and conditions and was generally "master of the situation". ${ }^{3}$ In contrast, although the union in Liverpool now had three branches with a combined membership of $10,000^{4}$ this represented less than half the total number of dockers. Some dockers held aloof from the union either because they belonged to other, and rival, societies or because it was said they did not believe in the movement or were indifferent about it. Among competing organisations were the South End Association, an old established benefit society the Clarence Dock Club, confined to men in the coasting trade, and the new Bootle assembly of the Knights of Labour which was actively recruiting dock labourers and stevedores. ${ }^{5}$ Nevertheless the Liverpool

1 Ibid., 1 June 1889. Nevertheless the Birkenhead branch of the union soon established a fund to provide for accidents and sickness with weekly contributions of $2 \mathrm{~d}$ - over and above the "labour", or strike fund, to which dues of $3 d$ a week were paid.

- Birkenhead News, 1 February 1890.

3 Halfpenny Weekly, 22 February 1890.

4 Liverpool Weekly Courier, 15 February 1890.

5 For details of the conflict between the Knights and Dock Labourers union see R. Bean, "A note on the Knights of Labour in Liverpool, 1889-90", in: Labor 
branches felt strong enough to announce a code of substantive rules for raising certain wage rates, regulating conditions of employment and levelling up standards all along the docks to those of the best employers. The rules specified a nine hour night for the northern docks as already applied at the south end and detailed fixed hours of work and meal breaks, or penalty overtime rates in lieu, in order to remedy the irregular practices which had grown up. The aim was to secure order by codification and an explicit formulation of rules which would limit the range of employer discretion. The rules also established for the first time, a wage list with higher differential rates for more arduous work such as grain handling. ${ }^{1}$ Some employers were prepared to accept the rules but union policy towards the majority who remained adamant was not to attempt enforcement on a general basis until its organisation had been strengthened. Recruitment was to be stepped up by means of a series of mass meetings in February addressed by John Burns and Ben Tillett, who had led the successful strike in the London docks. ${ }^{2}$

In fact, one particular occupational work group of dockers, the grain handlers, forced the issue by taking precipitate action independently of the union. The original source of their grievances was the introduction of the "devil", or elevator, for discharging grain from the holds of steamers. This work was extremely arduous and had been done by "bushellers" who filled the grain bags by means of a large measure called a bushel, and sack carriers who carried the bags on their backs. It was estimated that one man could carry as much as forty five tons a day. ${ }^{3}$ But mechanisation now meant that one elevator and six men could do the work of fifty labourers, thus discharging ships not only more quickly but also at less cost. ${ }^{4}$ The problem for the grain handlers was not only reduced employment but the destruction of a craft in that feeding, or "trimming", the elevators was regarded as a less skilled occupation. ${ }^{5}$ Yet, paradoxically, this technical change had enhanced the strategic position of the grain men; although only six to eight men were employed on each elevator a strike by them would effectively stop the whole of the discharging operations. Also,

History, XIII (1972). Also, the NUDL attempted to take over the membership of the Clarence Dock Club but its efforts were resisted. Liverpool Daily, April 1890.

1 Liverpool Weekly Post, 25 January 1890.

2 Liverpool Courier, 8 February 1890.

3 Ibid., 4 September 1889 . Piecework had been the wage payment system for bushelling corn.

4 Liverpool Daily Post, 26 July 1888. The first strike in Liverpool against the elevator took place at this time.

5 J. Lovell, op. cit., p. 52. 
despite the introduction of the elevator the work was still demanding as grain had to be conveyed from the hold to the elevator by means of pushing a steam "plough", so that the grain handlers would be struggling along knee-deep in grain for several hours at a time. Because a certain amount of skill and experience was required grain men could not be immediately replaced.

This improved bargaining position was further strengthened by the arrival in mid-January of an enormous quantity of Indian wheat, making employers still more vulnerable to labour pressure. The grain handlers quickly exploited their advantage by staging a number of sporadic strikes for the higher pay which union rules required. But when some employers conceded the $6 /-$ a day for trimming elevators the men then demanded $7 /-$, together with the removal of the elevators. ${ }^{1}$ Such demands were not part of union policy and did not have the authority, or prior knowledge, of the local union executive. The situation, in fact, became chaotic when delegates from the Bootle branch went to advise grain men on strike in the Huskisson dock to resume work. The men refused to listen and indeed threatened to throw the delegates into the dock. Whereupon delegates from another branch arrived, and a telegram from union headquarters in Glasgow, instructing the men to stay out. ${ }^{2}$ The union's district secretary criticised these work group strikes as "irresponsible" and new rules were drawn up to impose fines on members who called strikes without union authority. ${ }^{3}$ However, the difficulties arising from such local initiatives were mainly a consequence of the union's own action in permitting sectional bargaining to enforce the rules in those cases "where the men have the power".4

This element of "unofficial" action which has often embarrassed union leaderships in more recent times became widespread throughout the docks over the question of working with non-unionists. In February the union in Liverpool had issued badges or "buttons" to distinguish members from non-members when looking for work. If the union could gain some control of the labour supply, by influencing employers' hiring procedures, this would aid recruitment and provide an effective sanction to ensure that dockers remained in continuous membership. But, as with the stevedores organisation in London, ${ }^{5}$ the union's official policy was not to insist on a complete closed-shop but only

1 Liverpool Courier, 3 March 1890.

${ }^{2}$ Liverpool Echo, 1 March 1890.

3 Liverpool Courier, 3 March 1890.

4 Liverpool Echo, 27 January 1890.

s. J. Lovell, op. cit., p. 79. 
"preference" of employment for union members. ${ }^{1}$ In Liverpool, however, union members began to refuse to work with any nonunionists and had walked off vessels on which such men were employed. Shipowners confirmed that both verbal and written confirmation had been received from local branch officials that this position would be maintained. ${ }^{2}$ It was also known that as from the first week in March wearing of the badge was to be made compulsory for members when working to "separate the sheep from the goats". This requirement would identify non-members and so put them under pressure to join the union. In fact, within the next fortnight an additional 3,000 members were recruited at an entrance fee of $2 / 6 \mathrm{~d}$. But some applications were unsuccessful as they had to be approved by the branch committee, to ensure that only bona-fide dock labourers were admitted. ${ }^{3}$

With a strengthened bargaining position, in conditions of improved trade, ${ }^{4}$ many dockers favoured more militant action to enforce official union terms and conditions, or their own interpretation of them, in the form of a general strike along the docks. They had been "simmering" for months past and despite attempts by local officials to restrain them they were now rearing to go. The elevator men's dispute having provided a catalyst, and the union rules a focus, strikes took place to enforce the rules not only on the grain ships themselves but also on other vessels belonging to firms in dispute, where dockers - all now wearing the button - refused to work with non-unionists. This more general turnout was further extended by the appearance on the docks of posters purporting to be signed by the national officials of the union. Members were instructed to "Strike! Strike! Strike!", not to work with non-unionists, and were promised weekly strike pay of $13 /-$. This manifesto was denounced as a forgery by Edward McHugh, the union's national secretary who had come from Glasgow to take charge of the agitation, and he repudiated the aggressive policy which it advocated. ${ }^{5}$ But given the circumstances of mass, spontaneous action which was gaining its own momentum the union felt itself, albeit reluctantly, "impelled on" and had to do what it could by "arranging matters" in

${ }^{1}$ Liverpool Courier, 3 March 1890. There had been no mention of preference of employment for unionists in the rules announced in January.

${ }^{2}$ Liverpool Echo, 8 March 1890.

3 Liverpool Courier, 11 March 1890.

4 Liverpool Daily Post, 3 March 1890. There was said to be at this time "a great decrease in the number of men formerly to be found at the docks in search of work".

${ }^{5}$ Liverpool Daily Post, 5 March 1890 . He was to claim later that the manifesto was the work of $\mathrm{T}$. Kierman, a former secretary of the Bootle branch of the union. 
order to regain control of the situation. It therefore instructed those men already out not to return except under the specified union conditions. ${ }^{1}$ By March 7th 20,000 men were out and the northern docks were at a standstill. In fact, the strike had occurred at an appropriate time for employers at the north end as many large Atlantic steamship vessels were still lying up at the end of the winter season. ${ }^{2}$ Work continued at the south docks, however, where members of the South End Association were not included in the ranks of the scabs, and for those other employers who accepted the Dock Labourers' Union rules. Some master stevedores at the south docks agreed to employ union men only and went directly to the union office for their labour. ${ }^{3}$

The growing unrest on the docks and strengthening of the union's organisation prior to the strike had induced shipping employers to have recourse to defensive measures for mutual protection. The Employers Labour Association (ELA) was set up in February as a permanent, consolidated organisation ${ }^{4}$ to deal with labour problems collectively in the event of strikes by dockers or seamen, or joint action by both as had been proposed. ${ }^{5}$ It would have an accumulated fund to enable resistance to strike demands as well as agents to supply information regarding surplus labour available in other parts of the country. This organisation began to bring replacements to work strike bound grain ships and, when the full strike commenced, it sent handbills all over the country offering terms of immediate work at the docks at 30/- a week, fares paid to Liverpool and a pair of new boots. Some of the early importees, stonemasons and quarrymen from Cornwall, claimed to have been brought to Liverpool under false pretences ostensibly for construction work on new docks. They refused to work when they found a strike in progress and ended up either at the workhouse or starving and penniless in the streets. In some cases the union paid their fares home. ${ }^{6}$ During the strike a total of 13,000 importees were brought to work at the docks but many left either because of the arduousness of the work, or from being "practically imprisoned" on the depot ship the City of Richmond in order to avoid molestation from unionists. It was said that many of them had

${ }^{1}$ Liverpool Echo, 5 March 1890.

2 Liverpool Mercury, 7 March 1890.

3 Ibicl., 11 March 1890.

4 A temporary local employers association had been formed in 1889 during a seamen's strike.

5 Liverpool Weekly Courier, 15 February 1890. The ELA members employed three-fifths of seamen and dock labourers in the port.

- Liverpool Weekly Courier, 5 March 1890. 
every appearance of "gaol birds, pigeon flyers and public house prowlers"1 and they were certainly not efficient. An employer later confirmed that their work was only one third of that obtained from regular dockers ${ }^{2}$ and they performed a "painfully pantomimic representation of a docker's duties".

However, the significance of the imported strikebreakers, or "knobsticks", was not only that they enabled work to re-commence at the northern docks, but that they provided a new focus for dockers' grievances. The regular men absolutely refused to work with them, even for those employers not in the ELA who had accepted the union rules. Thus, because a strike is a dynamic phenomenon the emphasis accorded to particular issues can alter during its course. In the early stages McHugh stressed the wage dispute of an additional shilling a day for grain men. When the ELA responded with its own set of rules which conceded the required $7 /-$ and other wage improvements, but sought to make general the ten hour night, ${ }^{3}$ the union's emphasis then shifted to securing improved hours of work as set out in the rules. Yet although the union sought to enlist public support by concentrating attention upon the economic dissatisfactions of wages and hours, always regarded as a legitimate source of grievance, ${ }^{4}$ to the rank-andfile job regulation appeared to be the paramount consideration throughout.

It is therefore quite evident that the strike was proving difficult to resolve not only because the issues were shifting rather than static, but because the contending parties had differing conceptions of which issues were important. Furthermore, on the question of hiring procedures the interests of employers and aspirations of dockers were so incompatible that no compromise was possible. The men sought greater job security in an open labour market by restricting hiring to union members only. But to the union leadership this matter was a secondary, or "side", issue. McHugh's position on it was equivocal; he himself saw no objection to members working with Liverpool nonunionists, but recognised that many members did refuse to work with them..$^{5}$ The union was far more concerned with the institutional needs of the organisation itself. It was later to use the button not primarily for purposes of securing job preferences but, by the device of changing it every three months, for distinguishing its own members in good

${ }^{1}$ Liverpool Courier, 18 March 1890.

2 Report of the Commission of Inquiry, op. cit., q. 364.

3 Liverpool Courier, 14 March 1890 . This was probably because of strong representation on the ELA of steamship employers at the north docks.

4 See A. W. Gouldner, Wildcat Strike (1954), p. 31.

- Liverpool Mercury, 11 March 1890. 
financial standing. By the end of 1890 the union had spent almost $£ 500$ on the cost of buttons alone. ${ }^{1}$ Similarly, during the strike the union did not press for acceptance of its rules essentially because of their content, or even their authorship on a unilateral basis. Their content was open to discussion with employers for settlement on "an amicable basis". ${ }^{2}$ Rather, the vital point was the existence of the rules and the need for the union to be a "recognised body" which some acceptance of the rules would imply.

For the majority of shipping employers, however, the strike was seen as a fundamental challenge to their own authority and absolute prerogatives over the labour force. The dockers' action over the past months in refusing to work alongside non-unionists or, even, on vessels where freight clerks were not in the union, together with the national implications of their organisation as evidenced by a boycott in Liverpool of ships from other ports where disputes were in progress - all these were regarded by employers as "an intolerable encumbrance in conducting their business". 3 They were more 1 econciled to combinations of workers to improve wages and hours; during the strike these issues were regarded as "comparatively trifling". 4 What was totally illegitimate, however, was any attempt to substitute union for employer control of hiring procedures; thereby preventing the port's continuing as an open labour market with an unrestricted labour supply. Arbitration, as suggested in the press, was not possible on such a matter of principle. Attempted mediation by the Chamber of Commerce was also spurned. No outside body could be permitted to impair shipowners' freedom to deal with their own labour problems. Thus for employers, who insisted on their absolute right to employ whom they chose, ${ }^{5}$ the strike was a power struggle in which "the real question [was] one of free trade in labour versus despotism". ${ }^{\text {T }}$ The problem was not to attempt to resolve each particular grievance but to reassert "who are to be the masters, those who pay or those who work".? This concept of the strike as a power struggle appeared to be confirmed by the inflammatory language that came to be used as the strike progressed and became more embittered. The employers were denounced by McHugh as "idlers, thieves, robbers and beggars", ${ }^{8}$ and

1 Liverpool Courier, 19 December 1890. The baclges cost $£ 4$ per 1,000.

2 Ibid., 12 March 1890.

3 Liverpool Mercury, 24 March 1890.

4 Liverpool Daily Post, 7 March 1890.

- Minutes of the Liverpool Steamship Owners Association, 11 March 1890

- Liverpool Courier, 12 March 1890.

7 Ibid.

8 Ibid., 5 February 1890. 
Cunninghame Graham, a sympathetic MP who had come to assist the strikers, spoke the language of class conflict. The strike was a "battle of capital against labour", there were also allusions to the French Revolution and a chance remark from a striker that the docks would become a "slaughterhouse" was widely quoted. ${ }^{1}$ Shipowners were more reticent in their public pronouncements about their dock employees but it was said that it might be imagined from some of their private conversations that they were discussing the "nigger slaves of their grandfathers". ${ }^{2}$

The reaction of other waterfront unions in Liverpool towards the strike, with the exception of the coalheavers and later the South End Association who both came out in support, was to place the interests of their own members above any considerations of solidarity with the dockers. Early in the strike overtures had been made to the seamen and carters for concerted action against employers in order to bring the port to a standstill. ${ }^{3}$ At first the sailors and firemen's union refused to take ships to sea which had been loaded by non-unionists. But they relented when the steamship owners agreed to their own demands for 10/- a month pay increase, on condition that this objection was waived. ${ }^{4}$ The dockers felt that they had been "sold" and McHugh stated that the seamen had done a "foolish and short sighted thing". ${ }^{5}$ The newly formed carters' union, a substantial benefit society with 4,000 members, was similarly eclectic in its interests and sought to emphasise its separateness from other organisations of port workers. ${ }^{6}$ Its members had voted overwhelmingly against joining the strike, although five hundred carters did come out with the dockers for a short time unofficially. The flatmen who brought coal to the Atlantic liners had originally struck on a grievance of their own, but agreed to prolong their stoppage provided that the dockers continued to work for "friendly" employers. The leadership of the dockers' union was very willing to do this but its members, many of whom were dissatisfied that some dockers were still receiving wages during the strike, again took a different view. Another unofficial handbill called out three thousand unionists working for those employers who had agreed to union terms. ${ }^{7}$ After a mass meeting at which the men endorsed this

1 Ibid., 14 March 1890. Four days later magistrates voted to bring troops to the city.

2 Liverpool Citizen, 19 March 1890

3 Liverpool Courier, 7 March 1890.

4 Minutes of the Liverpool Steamship Owners Association, 11 March 1890.

5 Liverpool Mercury, 21 March 1890.

- Liverpool Review, 29 March 1890.

7 Liverpool Courier, 15 March 1890. 
action the leaders felt compelled to follow opinion and extend the stoppage. McHugh, however, regarded it as "suicidal" and hinted during the meeting at his possible resignation as strike leader. ${ }^{1}$ The results of this action were that the flatmen returned to work and the ranks of the ELA, which had not been fully representative, were strengthened by the addition of firms which had previously conceded the union terms but now withdrew them. ${ }^{2}$

By the fourth week of the strike there was acute distress among dockers' families, many of whom had been reduced to pawning their household effects as a means of survival. ${ }^{3}$ Some relief had been provided by a public voluntary committee and, for children, by the efforts of the police in Bootle. ${ }^{4}$ The union was also giving relief tickets to the value of $5 /$ - for the more desperate cases. But, unlike the situation in the London dock strike there had been no strike pay or outside subscriptions. The London dockers in fact offered financial support but it was not taken up by the strike leaders. ${ }^{5}$ Many of the strikers were by this time demoralised and ready to go back on the employers' terms. It had already been agreed to resume work again for employers who accepted the union rules. Furthermore, the men had moderated their own demands and refusal to work with Liverpool non-unionists or importees, provided they were kept apart from union members, had been waived as a condition for a general resumption. ${ }^{6}$ But the difficulty was that the ELA now sensing victory refused to accept such concessions as a basis for settlement, or to negotiate through the union. It required mediation by the Irish Nationalist Michael Davitt, in Lancashire to attend a political meeting, to persuade the ELA and independent shipowners to reopen negotiations directly with a deputation of the men. On the last day of March a settlement was agreed whereby the dockers secured regular meal hours, a nine hour night, and the offer of weekly employment as a substitute for the casual system. ${ }^{7}$ In return the men agreed to work alongside non-unionists and importees alike and that no badges would be worn at work. These terms were an improvement on conditions at the north end prior to

1 Ibid., 18 March 1890 . Mass meetings were held daily in order to provide information, ascertain opinion and encourage solidarity.

2 Liverpool Mercury, 15 March 1890.

3 Liverpool Daily Post, 21 March 1890.

4 Liverpool Courier, 29 March 1890.

5 This was confirmed by Tom Mann who addressed a number of strike meetings in Liverpool. Liverpool Daily Post, 28 March 1890.

B Liverpool Courier, 24 March 1890.

7 The union saw this as an obvious limitation on its own attempts at job control and later prohibited members accepting employment at weekly wages. Liverpool Courier, 5 November 1890 . 
the strike but were less favourable than those under which Birkenhead members were already working. The Birkenhead branch had come out in support of the Liverpool men and were "exasperated" at the settlement which also applied to them, and bitter that they had not been consulted prior to acceptance. ${ }^{1}$

We can conclude from this analysis that despite differing and changing conceptions of which issues were central to the strike disagreement about economic relations concerning wages and hours cannot explain its intractability nor the bitterness which it aroused. More fundamentally, the strike was rooted in differences over values and principle it had been about job regulation, equity and uniformity of treatment for employees, and employer prerogative deriving from property rights. In particular, the strike pointed to growing instability of waterfront industrial relations because of basic inconsistencies between the contending parties concerning the appropriate functions of worker organisations. In this respect it had been a struggle about collective relationships and the need to come to terms with each other as a body. The strike had thus confirmed, yet not without reluctance, a movement away from autonomous and fragmentary regulation by small groups of employees and individual employers towards a wider coverage of the unit of regulation; one which would be subject to approval of external authority as represented by the union or employers association. A new structural dimension had been added.

However, it would be wrong to regard the strike as a contest between a homogeneous union and a united body of employers. We have shown that there were divergent and conflicting interests within each of these organisations as well as between them. For the union the problem throughout had been to restrain and control its members' actions in the union's own long-term interests. Similarly, there had been disagreements between employers about how to respond to the union's challenge and a refusal by some of them to relinquish their self-sufficiency in labour matters and join the ELA. As regards other waterfront unions in Liverpool, the strike had also demonstrated that the "new" unionism, far from being a cohesive movement bound together by a common ideology, was torn by factional considerations and concern for self-interest. However, probably the most significant aftermath of the strike was that the docker's union, although it had not gained the recognition which it sought, continued thereafter to challenge shipowners' rights to unilateral control of employment

1 Ibid., 7 April 1890. 
relations. ${ }^{1}$ The employers association in turn fought to resist encroachment and thus, despite the absence of formal recognition, the union and ELA had necessarily to take account of each others actions. Moreover, both were to remain as permanent organisations on the Mersey waterfront.

1 For example by pursuing a policy of "ca'canny", whereby dockers determined the pace at which work would proceed. 